\title{
DETERMINASI MANAJEMEN KEUANGAN PRIBADI MAHASISWA
}

\author{
PRIHATININGSIH \\ Politeknik Negeri Semarang \\ atin3r@gmail.com
}

\begin{abstract}
This study aims to find out and analyze the factors that affect students' financial management ability. A sample of 100 students from Politeknik Negeri Semarang, Universitas Diponegoro dan Universitas Negeri Semarang with multiple Linear regression analysis tools after passing the validity test, reliability test and classic assumption test. Based on statistical test results obtained, financial education variables, financial literacy, academic ability, and work experience have a positive and significant effect on student personal financial management variables.
\end{abstract}

Keywords: Financial Management, Education in Collage, Financial Literacy, Academic Ability and Work Experience

Abstrak: Penelitian ini bertujuan untuk mengetahui dan menganalisis faktor-faktor yang mempengaruhi kemampuan manajemen keuangan pribadi mahasiswa. Sampel mahasiswa sebanyak 100 yang berasal dari Politeknik Negeri Semarang, Universitas Diponegoro dan Universitas Negeri Semarang dengan alat analisis regresi Linear berganda setelah lolos uji validitas, uji reliabilitas serta uji asumsi klasik. Berdasarkan hasil uji statistik diperoleh hasil bahwa variabel pendidikan keuangan, literasi keuangan, kemampuan akademik, dan pengalaman kerja berpengaruh positif dan signifikan terhadap variabel manajemen keuangan pribadi mahasiswa.

Kata kunci: Manajemen Keuangan, Pendidikan Keuangan, Literasi Keuangan, Kemampuan Akademik, dan Pengalaman Kerja

\section{Pendahuluan}

Era Revolusi industri 4.0 merupakan masa dimana teknologi informasi berkembang dengan sangat cepat yang membuat segala sesuatu menjadi lebih mudah, sehingga masyarakat terutama mahasiswa dimanjakan dengan teknologi yang ada. Media sosial dan internet menjadi wadah utama untuk menyebarkan dan mempromosikan berbagai macam hal baik barang maupun jasa. Hal ini memudahkan bertemunya penjual dan pembeli dalam transaksi online. Para pembeli dengan mudah mendapatkan barang yang diinginkan tanpa harus keluar dari rumah, dengan sekali klik, dan terdapat beragam jenis barang serta harga yang dapat dipilih sesuai selera masing-masing. Hal ini juga memicu timbulnya perilaku konsumtif masyarakat, khususnya di kalangan mahasiswa. Apalagi mahasiswa yang cenderung mengikuti tren akan mudah tergiur dengan upgrade suatu barang dari berbagai macam brand. Untuk itu, sebagai mahasiswa perlu adanya manajemen keuangan yang baik dan tekad yang kuat untuk mengontrol keinginan sehingga tidak mudah menghamburkan uang untuk hal-hal yang sebenarnya kurang bermanfaat atau kurang diperlukan.

Deyola (2014), berkaitan dengan alokasi anggaran mahasiswa dalam satu bulan yaitu pengeluaran yag digunakan untuk kebutuhan yang bersifat kesenangan (nonton di bioskop, pulsa maupun berbelanja) dimana pengeluaran tersebut justru lebih tinggi jika dibandingkan dengan pengeluaran kebutuhan mahasiswa seperti pendidikan maupun tabungan. Misalnya saja mahasiswa di program studi manajemen pada suatu Universitas Negeri di Jakarta angkatan 2013 untuk kategori tidak kos, persentase rata-rata dihabiskan untuk hiburan yakni 30,94\% (misalnya untuk pulsa 6,86\%, nonton di bioskop sebesar $6,71 \%$, belanja sebesar $14,90 \%$ ) dan untuk pendidikan adalah sebesar $5,96 \%$, dan untuk kesehatan yakni $1,49 \%$. Demikian pula, dana tabungan rata-rata menyumbang $7,49 \%$. Data 
tersebut menunjukkan bahwa para mahasiswa tersebut kurang tertarik dengan menabung dan kurang bisa mengelola keuangannya.

Mahasiswa merupakan bagian dari masyarakat yang relatif besar dan harus memiliki pribadi yang mandiri, terlebih dalam pengelolaan keuangan (Nababan dan Sadalia, 2012). Menurut Suryanto (2017), sebagian besar mahasiswa mengalami masalah dalam mengelola uang, terutama mahasiswa yang tidak berada di rumah dengan orang tuanya. Beberapa dari masalah ini dapat disebabkan oleh terlambatnya pengiriman uang dari orang tua, penggunaan uang yang habis lebih awal karena kebutuhan mendesak, bahkan parahnya adalah karena pengelolaan keuangan yang buruk.

Mahasiswa yang memiliki pengetahuan tentang manajemen keuangan diharapkan memiliki kemampuan mengelola keuangan pribadi yang baik (Wulandari dan Hakim, 2015). Mengingat mahasiswa merupakan calon profesional dibidangnya masing-masing dan pemimpin, maka harus mampu mengelola keuangan dengan baik dimasa yang akan datang, sehingga penting juga untuk memahami kecintaan mahasiswa terhadap uang. Danes dan Hira (1987) berpendapat bahwa mempelajari pengelolaan uang (financial management) merupakan hal terpenting yang meski dipunyai oleh seseorang. Dalam riset keuangan bidang ini biasanya membahas masalah-masalah berkaitan dengan keuangan individual, yang disebut dengan keuangan pribadi (Wulandari dan Hakim, 2015). Mengingat peran yang vital di masa depan, maka dalam penelitian ini membahas dan menganalisis pengelolaan keuangan pribadi mahasiswa beserta faktor yang memengaruhinya.

Berdasarkan kuesioner sederhana yang telah disebar kepada dua puluh orang mahasiswa, diperoleh hasil $80 \%$ mahasiswa setuju bahwa dirinya adalah seorang pengelola keuangan yang baik, akan tetapi hasil ini tidak sesuai dengan resume hasil pengisian butir-butir pertanyaan berikutnya dimana mereka jarang memiliki uang saku bulanan tersisa, mengalami masalah dalam mengelola pengeluaran pribadinya selama satu periode, kadang-kadang meminjam uang kepada teman dikarenakan beberapa hal yaitu mereka jarang mengecek saldo rekening secara rutin dan mahasiswa kadang-kadang tidak mengingat pengeluaran apa saja yang digunakan pada hari tersebut sehingga ketika dana mereka habis. Mereka tidak ragu membeli barang yang benar-benar mereka inginkan padahal belum tentu barang tersebut merupakan suatu kebutuhan dan keharusan. Perilaku di atas tidak akan terjadi jika mahasiswa memiliki perencanaan keuangan yang baik dan konsisten dalam pelaksanaanya.

Pendidikan keuangan mempunyai dampak cukup penting untuk siswa guna memberikan bekal skill tentang pemahaman, penilaian serta tindakan dalam pegelolaan keuangan pribadi (Jhonson \& Margaret, 2007). Kegiatan pembelajaran yang diperoleh dalam perguruan tinggi dapat berperan sebagai bekal bagi mahasiswa, sehingga dapat dimanfaatkan sebagai bekal dalam pengelolaan masalah keuangan yang akan dihadapinya. Penelitian terdahulu menunjukkan pendidikan keuangan memiliki dampak positif serta signifikan terhadap manajemen keuangan pribadi (Erawati dan Susanti, 2013; Wulandari dan Hakin, 2015), namun hasil berbeda diperoleh yang Herawati (2015) menunjukkan pendidikan keuangan tidak memiliki pengaruh terhadap perilaku keuangan mahasiswa.

Faktor lainnya adalah literasi keuangan yang dapat menjadi pemicu utama yang menentukan perilaku mahasiswa dalam pengelolaan keuangannya. Warsono $(2010,138)$ mengungkapkan pemahaman literasi keuangan dalam segala aspek pengelolaan keuangan pribadi bukanlah menjadikan sulit maupun membatasi untuk menikmati hidupnya, namun melalui literasi keuangan, individu hingga keluarga justru akan dapat menikmati hidupnya dengan menggunakan sumber daya keuangan secara sesuai untuk menggapai pengelolaan keuangan pribadi. Sekalipun sumber daya keuangan terbatas, jika seseorang dapat menyeimbangkan pengetahuan keuangannya yang baik, tentu akan memudahkan seseorang untuk mencapai tujuan hidupnya dan dapat mengontrol uang dengan tepat. Penelitian oleh Erawati dan Susanti (2013) menunjukkan hasil bahwa literasi keuangan memiliki pengaruh positif dan 
signifikan terhadap manajemen keuangan mahasiswa. Yushita (2017) mengungkapkan bahwa hasil penelitian secara umum membuktikan nahwa Indonesia sebagai negara berkembang mempunyai tingkat pengetahuan keuangan yang rendah, mengingat tingkat pengetahuan keuangan berdampak positif terhadap inklusi keuangan dan perilaku, situasi ini merupakan masalah yang serius.

Kemampuan akademik juga diduga mempunyai dampak terhadap perilaku keuangan mahasiswa. Mahaiswa dengan kemampuan akademis tinggi cenderung lebih memahami konsep keuangan. Sabri dan Gudmunson (2012) mengungkapkan bahwa kemampuan akademik mahasiswa yang tinggi ditunjukkan dengan nilai yang mencerminkan pengetahuan dan kemampuan siswa untuk belajar dan mengaplikasikan informasi yang didapatnya, sehingga hal ini menunjukkan bahwa dimungkinkan seorang mahasiswa untuk berhasil dalam mengatur keuangan pribadinya. Penelitian terdahulu meunjukkan bahwa kemampuan akademik berpengaruh signifikan terhadap manajemen keuangan mahasiswa (Putri, 2017; Wulandari dan Hakim, 2016), sedangkan hasil penelitian Laily (2013) mengungkap bukti lain bahwa kemampuan akademik justru tidak berpengaruh terhadap manajemen keuangan.

Pengalaman kerja sangat erat kaitannya dengan pengelolaan keuangan pribadi. Sina (2015) menunjukkan pengalaman memegang karakter penting terhadap keuangan pribadi karena dapat dijadikan materi pembelajaran untuk mencapai financial freedom. Hal ini dapat dilihat dari kekeliruan tindakan seseorang pada masa lalu dalam pengelolaan keuangan, kekeliruan dalam pengelolaan keuangan memungkinkan orang untuk belajar dari pengalaman supaya tidak terjadi kekeliruan di kemudian hari. Diyakini bahwa orang dengan pengalaman kerja yang tinggi akan membuat keputusan keuangan yang lebih cerdas daripada mereka yang tidak memiliki pengalaman kerja. Ini terjadi karena semakin sering seseorang terpapar masalah keuangan, semakin tinggi pengetahuannya dan semakin baik keputusan keuangannya. Hasil penelitian terdahulu mengungkapkan bahwa pengalaman bekerja mempunyai dampak yang signifikan pada manajemen keuangan (Erawati dan Susanti, 2013), namun hasil penelitian Laily (2013) justru menunjukkan hasil bahwa pengalaman bekerja tidak mempunyai pengaruh yang signifikan dalam manajemen keuangan.

Tujuan yang akan dicapai dalam penelitian ini yaitu mengetahui dan menganalisis faktor-faktor yang mempengaruhi kemampuan memanajemen keuangan pribadi mahasiswa. Kerangka pemikiran dalam penelitian ini tertuang dalam gambar 1.



Gambar 1 Kerangka Penelitian

Berdasarkan kerangka penelitian yang terdiri dari masing-masing variabel yaitu Pendidikan di Perguruan Tinggi, Literasi Keuangan, Kemampuan Akademik, serta Pengalaman Kerja terhadap Manajemen Keuangan Pribadi Mahasiswa, maka dapat disusunlah 4 hipotesis berikut:

$\mathrm{H}_{1}$ : Diduga variabel pendidikan di perguruan tinggi secara parsial berpengaruh positif dan signifikan terhadap manajemen keuangan pribadi mahasiswa. 
$\mathrm{H}_{2}$ : Diduga Literasi keuangan secara parsial berpengaruh positif dan signifikan terhadap manajemen keuangan pribadi mahasiswa.

$\mathrm{H}_{3}$ : Diduga Kemampuan akademik secara parsial berpengaruh positif dan signifikan terhadap manajemen keuangan pribadi mahasiswa.

$\mathrm{H}_{4}$ : Diduga Pengalaman kerja secara parsial berpengaruh positif dan signifikan terhadap manajemen keuangan pribadi mahasiswa.

\section{Metode Penelitian}

Populasi dalam penelitian ini adalah mahasiswa di Kota Semarang, sedangkan pengambilan sampel menggunakan teknik non probably sampling yaitu setiap populasi mendapatkan kesempatan yang sama untuk terpilih menjadi sampel dalam penelitian. Jumlah sampel pada penelitian ini yaitu seratus mahasiswa di Kota Semarang. Metode pengumpulan data primer ini dilakukan dengan membagikan kuesioner. Kuesioner ini akan disebarkan kepada sejumlah mahasiswa menggunakan platform google form.

Uji instrumen data menggunakan uji validitas dan reliabilitas. Dalam pengujian validitas, suatu data dapat dikatakan valid jika memiliki tingkat signifikasi $<0,05$ atau $5 \%$ atau nilai $r_{\text {hitung }}>r_{\text {tabel, }}$, sebaliknya jika $r_{\text {hitung }}<r_{\text {tabel }}$ maka data tersebut tidak valid (Ghozali, 2018:52). Untuk menguji reliabilitas suatu konstruk atau variabel dikatakan reliabel jika memberikan nilai Cronbach Alpha > 0,70 (Ghozali, 2018:46).

Uji asumsi klasik digunakan dalam penelitian ini yakni uji normalitas, uji heteroskedastisitas, uji multikolinearitas, serta uji autokorelasi. Model regresi yang baik adalah memiliki distribusi data normal atau mendekati normal. Pengujian normalitas dapat dilakukan dengan uji Non Parametric KolmogorovSmirnov (K-S) dengan nilai signifikan > 0,05, maka residual dikatakan berdistribusi normal (Ghozali, 2018:165). Model regresi yang baik yakni homoskedastisitas atau tidak terjadi heteroskedastisitas. Apabila variance dari residual suatu pengamatan ke pangamatan yang lain bersifat tetap, maka dapat disimpulkan terjadi homoskedastisitas dan jika berbeda maka daoat disimpulkan terjadi heteroskedastisitas (Arikunto, 2005). Pengujian heteroskedastisitas dapat dilakukan dengan uji Glejser dengan nilai signifikansi > 0,05 dapat dikatakan model regresi tidak terdapat gejala heteroskedastisitas. Uji multikolinearitas berguna untuk mengetahui ada tidaknya korelasi yang signifikan antar variabel bebas yang diuji pada model regresi linier berganda (Ghozali, 2005). Model regresi yang baik seharusnya tidak terjadi korelasi diantara variabel bebas. Uji multikolinearitas dapat dilihat dari nilai VIF (Variance Inflation Factor) $\leq 10$, dan nilai tolerance variabel independen $\geq 0,10$. Uji autokorelasi dapat dilakukan dengan Uji Durbin Watson. Model yang baik adalah yang bebas autokorelasi, dengan syarat 4-dl $<$ d $<4$ (Ghozali, 2018:112).

Dalam penelitian ini definisi operasional variabel adalah sebagai berikut :

1. $X_{1}$. Pendidikan keuangan adalah mempelajari materi keuangan yang berkaitan dengan literasi keuangan mahasiswa (Herawati, 2015).

2. $\mathrm{X}_{2}$. Literasi keuangan adalah kemampuan dan keahlian seseorang untuk mengelola sumber dayanya untuk mencapai tujuan keuangan saat ini dan masa depan (Herawati, 2015).

3. $X_{3}$. Kemampuan akademik menurut Sabri dan Gudmunson (2012) nilai indeks prestasi (IP) menunjukkan bahwa kemampuan akademik siswa yang tinggi mencerminkan pengetahuan dan kemampuan siswa untuk belajar serta menerapkan informasi yang diperoleh.

4. $\mathrm{X}_{4}$ Pengalaman kerja adalah ukuran lamanya waktu atau tahun yang dibutuhkan seseorang untuk memahami tanggung jawab pekerjaan tertentu dan melaksanakan pekerjaan dengan benar (Foster, 2001).

5. Y. Manajemen keuangan pribadi mahasiswa adalah segala bentuk kegiatan administrasi yang 
dilakukan secara berjenjang: perencanaan, penyimpanan, penggunaan, pencatatan dan pemantauan, serta mengakhiri pertanggungjawaban (pelaporan) dana pribadi siswa / uang masuk dan keluar kegiatan pada waktu tertentu. (Putri, 2017).

Model persamaan dalam riset ini yaitu model regresi linier berganda dan diolah dengan aplikasi SPSS 21. Persamaan regresi yang digunakan yaitu:

$Y=a+b 1 X_{1}+b 2 X_{2}+b 3 X_{3}+b 4 X_{4}+e$

Dimana:

$\begin{array}{llll}\mathrm{a} & =\text { Konstanta } & \mathrm{X}_{3} & =\text { Kemampuan akademik } \\ \mathrm{b} & =\text { slope } & \mathrm{X}_{4} & =\text { Pengalaman kerja } \\ \mathrm{X}_{1} & =\text { Pendidikan keuangan } & \mathrm{Y} & =\text { Manajemen keuangan pribadi } \\ \mathrm{X}_{2} & =\text { Literasi keuangan } & \mathrm{e} & =\text { Error }\end{array}$

\section{Hasil dan Pembahasan}

Hasil pengujian kualitas data yang dilakukan dengan pengujian validitas menunjukkan kualitas pelayanan yakni pendidikan di perguruan tinggi, literasi keuangan, kemampuan akademik, pengalaman kerja serta manajemen keuangan pribadi mahasiswa mempunyai nilai $\boldsymbol{r}_{\text {hitung }}>$ nilai $r_{\text {tabel }}$ sehingga data dikatakan valid serta nilai cronbach's alpha $>0,7$ sehingga dapat disimpulkan bahwa butir-butir pernyataan dalam kuesioner reliabel. Hasil pengujian validitas dan reliabilitas dapat dilihat pada tabel 1 dan 2.

Tabel 1 Hasil Uji Validitas

\begin{tabular}{|c|c|c|c|c|}
\hline No & Variabel dan Indikator & $r_{\text {hitung }}$ & $\mathbf{r}_{\text {tabel }}$ & Keterangan \\
\hline \multirow[t]{4}{*}{1} & Pendidikan Keuangan $\left(\mathrm{X}_{1}\right)$ & & & \\
\hline & $X_{1.1}$ & 0,837 & 0,1966 & Valid \\
\hline & $X_{1.2}$ & 0,867 & 0,1966 & Valid \\
\hline & $X_{1.3}$ & 0,832 & 0,1966 & Valid \\
\hline \multirow[t]{4}{*}{2} & \multicolumn{4}{|l|}{ Literasi Keuangan $\left(X_{2}\right)$} \\
\hline & $X_{2.1}$ & 0,877 & 0,1966 & Valid \\
\hline & $\mathrm{X}_{2.2}$ & 0,784 & 0,1966 & Valid \\
\hline & $\mathrm{X}_{2.3}$ & 0,784 & 0,1966 & Valid \\
\hline \multirow[t]{4}{*}{3} & \multicolumn{4}{|l|}{ Kemampuan Akademik $\left(X_{3}\right)$} \\
\hline & $X_{3.1}$ & 0,846 & 0,1966 & Valid \\
\hline & $X_{3.2}$ & 0,865 & 0,1966 & Valid \\
\hline & $\mathrm{X}_{3.3}$ & 0,772 & 0,1966 & Valid \\
\hline \multirow[t]{4}{*}{4} & \multicolumn{4}{|l|}{ Pengalaman Kerja $\left(X_{4}\right)$} \\
\hline & $\mathrm{X}_{4.1}$ & 0,798 & 0,1966 & Valid \\
\hline & $X_{4.2}$ & 0,814 & 0,1966 & Valid \\
\hline & $X_{4.3}$ & 0,794 & 0,1966 & Valid \\
\hline \multirow[t]{6}{*}{5} & Manajemen Keuangan Pribadi & & & \\
\hline & Mahasiswa $(Y)$ & 0,738 & 0,1966 & Valid \\
\hline & $Y_{1}$ & 0,766 & 0,1966 & Valid \\
\hline & $Y_{2}$ & 0,728 & 0,1966 & Valid \\
\hline & $Y_{3}$ & 0,704 & 0,1966 & Valid \\
\hline & $Y_{4}$ & & & \\
\hline
\end{tabular}

Sumber : Data Primer yang Diolah (2020) 
Tabel 2 Hasil Uji Reliabilitas

\begin{tabular}{clccc}
\hline No & \multicolumn{1}{c}{ Variabel } & $\begin{array}{c}\text { Cronbach's } \\
\text { Alpha }\end{array}$ & Kriteria & Keterangan \\
\hline 1 & Pendidikan Keuangan $\left(\mathrm{X}_{1}\right)$ & 0,801 & 0,700 & Realiabel \\
2 & Literasi Keuangan $\left(\mathrm{X}_{2}\right)$ & 0,748 & 0,700 & Realiabel \\
3 & Kemampuan Akademik $\left(\mathrm{X}_{3}\right)$ & 0,771 & 0,700 & Realiabel \\
4 & Pengalaman Kerja $\left(\mathrm{X}_{4}\right)$ & 0,724 & 0,700 & Realiabel \\
5 & Manajemen Keuangan Pribadi & 0,729 & 0,700 & Realiabel \\
& Mahasiswa $(\mathrm{Y})$ & & & \\
\hline
\end{tabular}

Sumber : Data Primer yang Diolah (2020)

Hasil pengujian normalitas pada tabel 3 dengan Kolmogorov-Smirnov test menghasilkan nilai Kolmogorov-Smirnov sebesar 0,078 dengan nilai signifikansi sebesar 0,137 atau lebih dari 0,05 yang berarti data terdistribusi normal.

Tabel 3 Hasil Uji Normalitas

\begin{tabular}{llr}
\multicolumn{3}{c}{ Tabel 3 Hasil Uji Normalitas } \\
One-Sample Kolmogorov-Smirnov Test \\
Unstandardized Residual \\
Normal Parametersa,b & Mean & 100 \\
& Std. Deviation &, 0000000 \\
Most Extreme & Absolute & 1,40298761 \\
Differences & Positive &, 049 \\
& Negative &, 039 \\
Test Statistic & &,- 049 \\
Asymp. Sig. (2-tailed) &, 078 \\
a. Test distribution is Normal. &, 137 c \\
b. Calculated from data. & \\
c. Lilliefors Significance Correction. & \\
\hline
\end{tabular}

Sumber: Data Primer yang Diolah (2020)

Hasil uji multikolinearitas pada tabel 4 menunjukkan bahwa masing-masing variabel independen memiliki nilai Tolerance lebih dari 0,10 serta nilai variance inflation factor (VIF) yang kurang dari 10, maka dapat disimpulkan data terbebas dari problem multikolineliearitas.

Tabel 4 Hasil Uji Multikoloniearitas

\begin{tabular}{lcc}
\hline \multicolumn{1}{c}{ Variabel } & \multicolumn{2}{c}{ Collinearity Statistics } \\
& Tolerance & VIF \\
\hline Pendidikan Keuangan $\left(X_{1}\right)$ &, 770 & 1,298 \\
Literasi Keuangan $\left(\mathrm{X}_{2}\right)$ &, 625 & 1,601 \\
Kemampuan Akademik $\left(\mathrm{X}_{3}\right)$ &, 726 & 1,377 \\
Pengalaman Kerja $\left(\mathrm{X}_{4}\right)$ &, 712 & 1,404 \\
a. Dependent Variable: Manajemen Keuangan Pribadi Mahasiswa $(\mathrm{Y})$ & \multicolumn{2}{c}{}
\end{tabular}

Sumber : Data Primer yang Diolah (2020)

Hasil autokorelasi pada tabel 5 menggunakan uji Durbin-Watson menunjukkan bahwa data tidak terjadi autokorelasi. Nilai Durbin-Watson (DW) sebesar 1,839, sedangkan berdasarkan tabel Durbin-Watson untuk $\mathrm{k}=4$ dan $\mathrm{N}=100$ besar nilai $\mathrm{dl}=1,5922$, $\mathrm{du}=1,7582$, maka nilai 4 -du $=$ 
2,2418, sehingga $1,7582(\mathrm{du})<1,839$ (DW) $<2,2418$ (4-du), yang berarti tidak ada autokorelasi dalam model regresi.

Tabel 5 Hasil Uji Durbin Watson

\begin{tabular}{cccccc}
\hline Model & $\mathrm{R}$ & $\mathrm{R}$ Square & $\begin{array}{c}\text { Mdjusted R } \\
\text { Square }\end{array}$ & $\begin{array}{c}\text { Std. Error of the } \\
\text { Estimate }\end{array}$ & Durbin-Watson \\
1 &, $923^{\mathrm{a}}$ &, 852 &, 845 &, 651 & 1,839
\end{tabular}

a. Predictors: (Constant), Pendidikan Keuangan (X1), Literasi Keuangan (X2), Kemampuan

Akademik (X3), Pengalaman Kerja (X4)

b. Dependent Variable: Manajemen Keuangan Pribadi Mahasiswa $(Y)$

Sumber : Data Primer yang Diolah (2020)

Hasil uji heteroskedastisitas pada tabel 6 dengan uji Glejser menunjukkan bahwa semua nilai signifikansi untuk masing-masing variabel independen lebih dari 0,05 , sehingga dapat disimpulkan bahwa model regresi tidak terdapat gejala heteroskedastisitas.

Tabel 6 Hasil Uji Heteroskedastisitas

\begin{tabular}{lcc}
\hline \multicolumn{1}{c}{ Variabel } & $\mathbf{t}$ & Sig. \\
\hline (Constant) & 3,349 &, 001 \\
Pendidikan Keuangan $\left(\mathrm{X}_{1}\right)$ &,- 117 &, 907 \\
Literasi Keuangan $\left(\mathrm{X}_{2}\right)$ &,- 699 &, 486 \\
Kemampuan Akademik $\left(\mathrm{X}_{3}\right)$ &,- 662 &, 510 \\
Pengalaman Kerja $\left(\mathrm{X}_{4}\right)$ &,- 121 &, 904 \\
a. Dependent Variable: abs_res & & \\
\hline
\end{tabular}

Sumber : Data Primer yang Diolah (2020)

Hasil Uji $F$ (model) pada tabel 7 menunjukkan hasil uji $F_{\text {hitung }}$ sebesar 136,288 dan signifikansi pada 0,000 (kurang dari 0,05 ). Hal ini menunjukkan bahwa model yang diuji dalam penelitian ini layak untuk dilakukan uji hipotesis.

Tabel 7 Hasil Uji F

\begin{tabular}{|c|c|c|c|c|c|c|}
\hline \multicolumn{7}{|c|}{ ANOVAa $^{a}$} \\
\hline \multirow{4}{*}{1} & Model & $\begin{array}{l}\text { Sum of } \\
\text { Squares }\end{array}$ & $d f$ & $\begin{array}{l}\text { Mean } \\
\text { Square }\end{array}$ & $\mathrm{F}$ & Sig. \\
\hline & Regression & 230,775 & 4 & 57,694 & 136,288 &, $000^{b}$ \\
\hline & Residual & 40,215 & 95 & ,423 & & \\
\hline & Total & 270,990 & 99 & & & \\
\hline
\end{tabular}

a. Dependent Variable: Manajemen Keuangan Pribadi Mahasiswa $(Y)$

b. Predictors: (Constant), Pendidikan Keuangan (X1), Literasi Keuangan (X2), Kemampuan Akademik (X3), Pengalaman Kerja (X4)

Sumber: Data Primer yang Diolah (2020)

Hasil Uji koefisien determinasi yang terdapat pada tabel 8 menunjukkan hasil bahwa koefisien determinasi (Adjusted $R$ Square) sebesar 0,852. Berarti variabel pendidikan di perguruan tinggi, literasi keuangan, kemampuan akademik, dan pengalaman kerja memberi kontribusi pengaruh terhadap manajemen keuangan pribadi mahasiswa sebesar $84,5 \%$. Kemudian tersisa sebesar $15,5 \%$ dipengaruhi oleh variabel lain yang tidak diteliti dalam penelitian ini. 
Tabel 8 Hasil Uji Koefisien Determinasi

\begin{tabular}{|c|c|c|c|c|c|}
\hline \multicolumn{6}{|c|}{ Model Summaryb } \\
\hline Model & $\mathrm{R}$ & R Square & $\begin{array}{c}\text { Adjusted R } \\
\text { Square }\end{array}$ & $\begin{array}{l}\text { Std. Error of the } \\
\text { Estimate }\end{array}$ & Durbin-Watson \\
\hline $\begin{array}{c}1 \\
\text { a. Pred } \\
\text { Akaden } \\
\text { b. Depe }\end{array}$ & $\begin{array}{l}923^{a} \\
\text { s: (Con } \\
\text { X3), Pe } \\
\text { int Varia }\end{array}$ & $\begin{array}{l}, 852 \\
\text {, Pendidika } \\
\text { aman Kerja } \\
\text { Manajemen }\end{array}$ & $\begin{array}{c}\text {,845 } \\
\text { euangan (X1), } \\
\text { uangan Pribac }\end{array}$ & $\begin{array}{l}\quad, 651 \\
\text { asi Keuangan (X2) } \\
\text { asiswa (Y) }\end{array}$ & $\begin{array}{l}1,839 \\
\text { mampuan }\end{array}$ \\
\hline
\end{tabular}

Sumber: Data Primer yang Diolah (2020)

Hasil Uji $\mathrm{t}$ (Hipotesis) pada tabel 9 menunjukkan nilai yang signifikan pada variabel Pendidikan Keuangan $\left(X_{1}\right)$, Literasi Keuangan $\left(X_{2}\right)$, Kemampuan Akademik $\left(X_{3}\right)$, Pengalaman Kerja $\left(X_{4}\right)$ terhadap Manajemen Keuangan Pribadi Mahasiswa $(Y)$. Sehingga seluruh hipotesis yang diuji dalam penelitian ini diterima karena nilai signifikansi berada dibawah 0,05.

Tabel 9 Hasil Uji t (Hipotesis)



Sumber: Data Primer yang Diolah (2020)

Berdasarkan hasil uji statistik diketahui bahwa variabel pendidikan keuangan yang diperoleh di perguruan tinggi memiliki pengaruh yang positif serta signifikan terhadap manajemen keuangan pribadi mahasiswa, hasil ini wajar karena seluruh responden merupakan mahasiswa Ekonomi. Hasil ini menunjukkan bahwa kemampuan mahasiswa dalam mengelola keuangan pribadinya sangat dipengaruhi oleh pengetahuan mengelola keuangan yang di peroleh dari bangku kuliah, misalnya melalui mata kuliah akuntansi perbankan, akuntansi perpajakan, akuntansi keuangan menengah, kewirausahaan, anggaran perusahaan, dan manajemen keuangan, sebagai penerapan ilmu yang diperolehnya dari perkuliahan ke praktik yang sederhana dan ini didorong juga oleh Dosen yang selalu mengingatkan dan memotivasi para mahasiswa untuk menerapkan ilmu tersebut dalam aplikasi yang sederhana yaitu mengelola atau memanajemen keuangan pribadinya. Hasil riset ini mendukung hasil penelitian Wulandari dan Hakim (2015) yang memperoleh hasil pendidikan memiliki pengaruh positif serta signifikan terhadap kemampuan mengelola keuangan pribadi.

Variabel literasi keuangan memiliki pengaruh positif serta signifikan terhadap manajemen keuangan pribadi mahasiswa. Hasil ini menunjukkan bahwa kemampuan mahasiswa dalam mengelola keuangan pribadinya sangat dipengaruhi oleh pengetahuan mengelola keuangan yang di peroleh dari orang tuanya, dari seminar, talk show dan diskusi terkait pengelolaan keuangan pribadi dan dari buku- 
buku keuangan yang dibaca oleh mahasiswa. Hasil penelitian ini selaras dengan hasil riset Widayati (2014), Erawati dan Susanti (2013) serta Laily (2013).

Variabel kemampuan akademik berpengaruh positif serta signifikan terhadap kemampuan manajemen keuangan pribadi mahasiswa. Hasil ini menunjukkan bahwa kemampuan mahasiswa dalam mengelola keuangan pribadinya sangat dipengaruhi oleh pemahaman mereka terhadap mata kuliah yang berkaitan dengan manajemen keuangan, penganggaran dan akuntansi sehingga Mahasiswa tersebut tidak menemui kesulitan dalam menerapkan pada keuangan pribadinya dengan membuat skala prioritas kebutuhan mereka sendiri. Hasil riset ini memberikan dukungan terhadap riset yang dilakukan oleh Safitri dan Sukirman (2018) dan Sabri et al. (2012) yang menyatakan bahwa kemampuan akademik yang diproksikan dengan indeks prestasi memiliki pengaruh positif dan signifikan terhadap terhadap kemampuan mengelola keuangan pribadi

Berdasarkan hasil pegujian statistik diketahui bahwa variabel pengalaman kerja ternyata memiliki pengaruh positif serta signifikan dalam manajemen keuangan pribadi mahasiswa. Hasil ini memberikan pandangan bahwa mahasiswa yang memiliki pengalaman kerja akan lebih menghargai nilai dari uang karena mahasiswa dapat merasakan perjuangan untuk menghasilkan uang sehingga menumbuhkan sikap sangat berhati-hati dan selektif dalam membelanjakan uang hasil jerih payah sendiri, hasil ini pencerminan dari $67 \%$ atau 67 orang responden merupakan mahasiswa yang memiliki pengalaman kerja paruh waktu. Hasil riset sejalan dengan Erawati dan Susanti (2013) yang memperoleh hasil pengalaman kerja memiliki dampak positif dan signifikan terhadap manajemen keuangan pribadi mahasiswa.

\section{Penutup}

Berdasarkan hasil analisis dan pembahasan yang telah dilakukan dalam penelitian ini mengenai Berdasarkan hasil analisis dan pembahasan tentang pengaruh pendidikan keuangan, literasi keuangan, kemampuan akademik, dan pengalaman kerja terhadap manajemen keuangan pribadi mahasiswa, maka kesimpulan yang dapat ditarik sebagai berikut: (1) pendidikan keuangan secara parsial berpengaruh positif dan signifikan terhadap manajemen keuangan pribadi mahasiswa, (2) literasi keuangan secara parsial berpengaruh positif dan signifikan terhadap manajemen keuangan pribadi mahasiswa, (3) kemampuan akademik secara parsial berpengaruh positif dan signifikan terhadap manajemen keuangan pribadi mahasiswa, dan (4) pengalaman kerja secara parsial berpengaruh positif dan signifikan terhadap manajemen keuangan pribadi mahasiswa.

Untuk meningkatkan kemampuan manajemen keuangan pribadi mahasiswa maka: (1) perguruan tinggi dapat memberikan muatan mata kuliah kewirausahaan atau manajemen bagi mahasiswa non ekonomi, (2) mendorong dan memfasilitasi mahasiswa melalui diskusi, seminar, dan talk show terkait pengelolaan manajemen keuangan pribadi, (3) mendorong dan memotivasi mahasiswa agar berprestasi dan belajar mengatur dan merencanakan keuangan pribadinya, dan (4) memberikan pemahaman tentang dunia kerja dengan melaksanakan program magang atau praktik kewirausahaan.

\section{Daftar Pustaka}

Danes, S.M. dan Hira, T.K. (1987). Money management knowledge of college students, Journal of Student Financial Aid, 17(1), 4-16.

Deyola, Y. (2014). Pengaruh Pengetahuan Keuangan dan Sikap Keuangan Terhadap Keputusan Menabung Pada Produk Tabungan Di Perbankan. Jurnal Keuangan Dan Bisnis, 114-141. 
Erawati, N. dan Susanti. (2017). Pengaruh Literasi Keuangan, Pembelajaran di Perguruan Tinggi, dan Pengalaman Bekerja terhadap Perilaku Keuangan Mahasiswa Fakultas Ekonomi Universitas Negeri Surabaya. Jurnal Pendidikan Akuntansi (JPAK), 5(1), 1-7.

Foster, B. S., dan Karen, R. (2001). Pembinaan Untuk Meningkatkan Kinerja Karyawan, PPM, Jakarta.

Ghozali, I. (2018). Aplikasi Analisis Multivariate dengan Program SPSS. Edisi Kesembilan. Semarang: Badan Penerbit Universitas Diponegoro.

Herawati, N. T. (2015). Kontribusi Pembelajaran di Perguruan Tinggi dan Literasi Keuangan terhadap Perilaku Keuangan Mahasiswa. Jurnal Pendidikan dan Pengajaran, 48(1-3), 60-70.

Jhonson, E., dan Margaret, S. S. (2007). From Financial Literacy to Financial Capability Among The Young. Journal of Sociology and Social Welfare, 34, 119-146.

Laily, N. (2016). Pengaruh Literasi Keuangan terhadap Perilaku Mahasiswa dalam Mengelola Keuangan. Journal of Accounting and Business Education, 1(4).

Nababan, D., dan Sadalia, I. (2012). Analisis Personal Financial Literacy dan Financial Behaviour Mahasiswa S-1 Fakultas Ekonomi Universitas Sumatera Utara.

Putri, Y. A. (2017). Pengaruh Pengetahuan Keuangan dan Pendidikan Keuangan di Keluarga terhadap Pengelolaan Keuangan Mahasiswa di Surabaya. Skripsi. Surabaya: STIE Perbanas.

Sabri, M. F., Cook, C. C., dan Gudmunson, C. G. (2012). Financial well-being of Malaysian college students. Asian Education and Development Studies, 1(2), 153-170.

Safitri, N. A. (2018). Analisis Faktor-Faktor yang Mempengaruhi Financial Behavior. Economic Education Analysis Journal, 7(2), 511-524.

Sina, P. G. (2015). Wealth Management Untuk Pensiun Yang Sejahtera. Jurnal Economia, 11(2), 186199.

Suryanto. (2017). Pola Perilaku Keuangan Mahasiswa di Perguruan Tinggi. Jurnal IImu Politik dan Komunikasi, 7(1), 11-20.

Warsono, W. (2011). Prinsip-prinsip dan Praktik Keuangan Pribadi. Jurnal Salam, 13(2).

Widayati, I. (2011). Pengaruh Status Sosial Ekonomi Orang Tua, Pendidikan Pengelolaan Keuangan Keluarga, dan Pembelajaran di Perguruan Tinggi Terhadap Literasi Finansial Mahasiswa. Jurnal Pendidikan Humaniora, 2(2), 176-183.

Wulandari dan Hakim, L. (2015). Pengaruh Love Of Money, Pendidikan Keuangan di Keluarga, Hasil Belajar Manajemen Keuangan, dan Teman Sebaya Terhadap Manajemen Keuangan. Jurnal Pendidikan Akuntansi, 3(3), 1-6.

Yushita, A. N. (2017). Pentingnya Literasi Keuangan bagi Pengelolaan Keuangan Pribadi. Nominal: Barometer Riset Akuntansi dan Manajemen, 6(1), 11-26. 